\title{
Aplikasi Penjualan Tunai Berbasis Web Pada CV. Damar Abadi Pontianak Pontianak
}

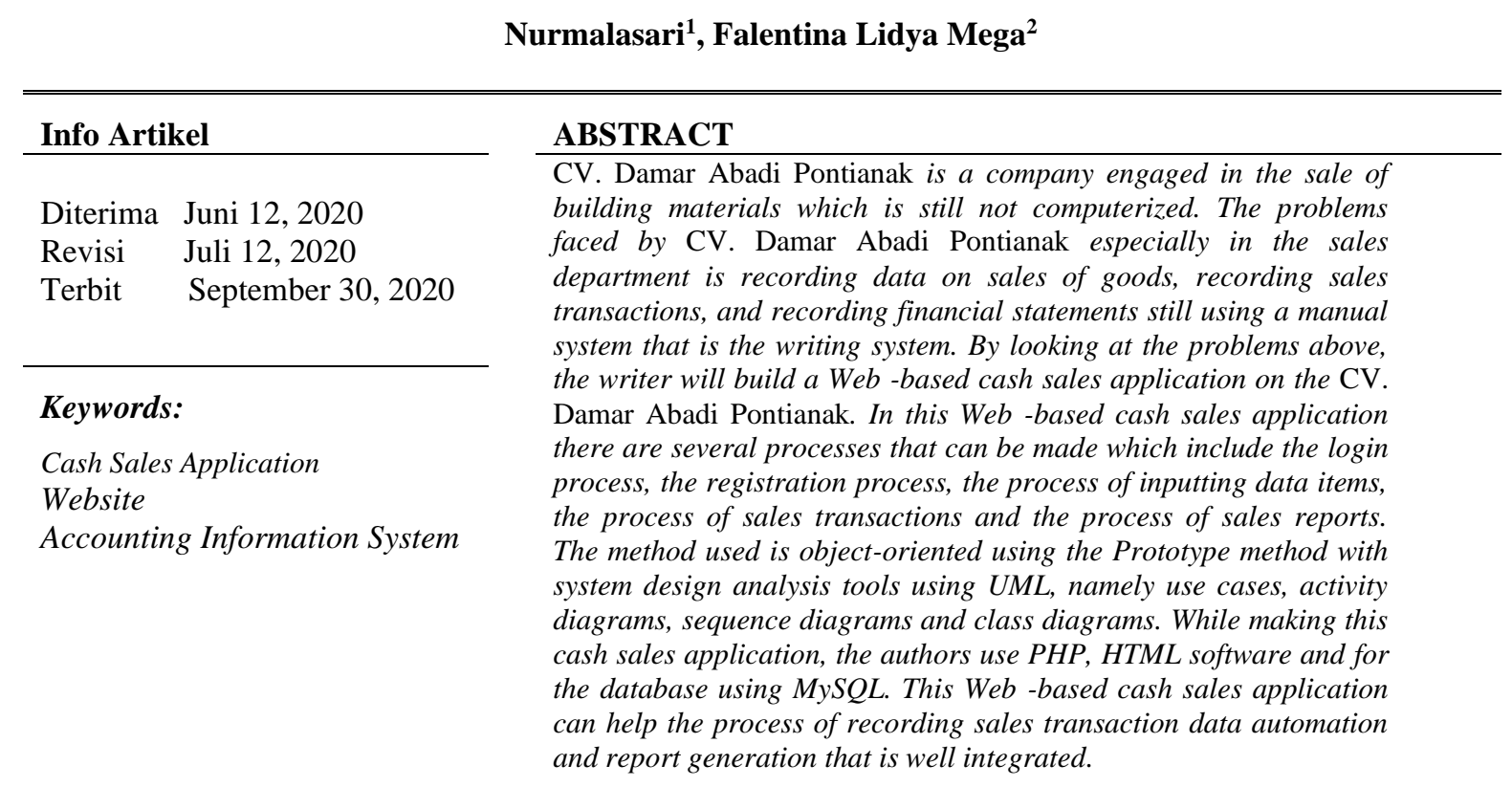

\section{Identitas Penulis:}

Nurmalasari ${ }^{1}$, Falentina Lidya Mega ${ }^{2}$

Universitas Bina Sarana Informatika Program Studi Sistem Informasi Akuntansi Kampus Pontianak Jalan Abdurrahman Saleh No.18 A Pontianak

Email: nurmalasari.nrr@bsi.ac.id ${ }^{1}$, falentinalidyamega@gmail.com ${ }^{2}$

\section{PENDAHULUAN}

Di masa sekarang ini, persaingan bisnis semakin meningkat tiap tahunnya diikuti juga dengan perkembangan teknologi. Perusahaan dituntut untuk dapat bertahan dalam persaingan global yang ada saat ini. Strategi yang tepat sangatlah dibutuhkan perusahaan agar dapat bertahan dalam persaingan global ini. Salah satu strategi yang dapat dilakukan adalah dengan mengurangi biaya, meningkatkan kualitas barang atau jasa, serta meningkatkan pelayanan bagi para pelanggan. Salah satu manfaat kemajuan teknologi adalah pengumpulan informasi yang lebih efektif dan efisien. Untuk itu diperlukan alat pendukung dalam pengumpulan dan pengelolahan informasi yaitu komputer.

Komputer merupakan media komunikasi yang sangat memungkinkan masyarakat untuk melakukan input dan output data dengan cepat dan praktis. CV. Damar Abadi Pontianak merupakan salah satu unit usaha yang bergerak dalam penjualan produk material bangunan. Dari kegiatan operasionalnya CV. Damar Abadi Pontianak belum terkomputerisasi karena masih menggunakan manual arsip dalam pengolahan data keuangan, oleh sebab itu untuk meningkatkan kinerja perusahaan CV. Damar Abadi Pontianak menuju kearah yang lebih baik lagi yaitu dengan melakukan pengolahan data yang terkomputerisasi.

Berdasarkan keterangan pemilik perusahaan CV. Damar Abadi Pontianak pengolahan data transaksi seperti pencatatan penjualan dan pembayaran, serta penghitungan laporan keuangan masih menggunakan sistem manual yaitu pencatatan masih menggunakan penulisan manual bahkan penulisan laporan yang di catat dalam buku besar pun masih belum dilakukan. Untuk mengetahui aset kekayaaan perusahaan hanya menghitung nota dari hasil penjualan yang di lakukan. Hal ini menimbulkan laporan keuangan yang tidak valid dalam penghitungan kekayaan yang dimiliki. 
Proses pencatatan kas yang masih manual menimbulkan masalah yaitu ketidakakuratan data, ketidakefisienan waktu dan biaya perusahaan. Untuk memenuhi kebutuhan pencatatan kas pada CV. Damar Abadi Pontianak maka solusinya adalah dengan menerapkan sistem yang terkomputerisasi.

\section{METODE}

\subsection{Metode Penelitian}

Pengumpulan data adalah faktor utama yang paling penting dalam keberhasilan penelitian. Hal ini berkaitan dengan cara mengumpulkan data, siapa sumbernya, dan apa alat yang digunakan. Dalam penelitian ini, memperoleh data yang diperlukan dengan cara sebagai berikut:

1. Observasi (Pengamatan)

Dalam metode ini dilakukan penelitian dengan menganalisis sistem yang berjalan, dengan cara mengadakan pengamatan langsung atau observasi lapangan melalui bagian administrasi dan mencari data yang diperlukan pada CV. Damar Abadi Pontianak di Jalan Adi Sucipto Km.11,8 Sungai Raya, Pontianak dalam penulisan laporan penelitian ini.

2. Wawancara (Interview)

Metode untuk mendapatkan data dengan cara mewawancarai secara lisan dan sistematis terhadap orang yang bersangkutan. Untuk mendapatkan informasi yang lebih jelas, dilakukan wawancara langsung dengan bagian admnistrasi keuangan yang bernama Tristania Palupi sebagai bendahara dan pemilik perusahaan CV. Damar Abadi Pontianak mengenai apa saja yang diinginkan dalam mengetahui tentang permasalahan yang sedang diamati untuk menyakinkan hal-hal kegiatan observasi yang telah dilakukan.

3. Studi Pustaka

Selain melakukan observasi dan wawancara, juga dilakukan pengumpulan data dengan cara studi pustaka, pada metode ini proses mengumpulkan beberapa referensi yang bersumber dari $e$-book, buku atau referensi - referensi.

\subsection{Metode Pengembangan Software}

"Metode pengembangan software yang digunakan adalah waterfall. Metode air terjun atau yang sering disebut metode waterfall sering dinamakan siklus hidup klasik (classic life cycle), dimana hal ini menggambarkan pendekatan yang sistematis dan juga berurutan pada pengembangan perangkat lunak, dimulai dengan spesifikasi kebutuhan pengguna lalu berlanjut melalui tahapan-tahapan perencanaan (planning), permodelan (modeling), konstruksi (construction), serta penyerahan sistem ke para pelanggan/pengguna (deployment), yang diakhiri dengan dukungan pada perangkat lunak lengkap yang dihasilkan [4].

Metode waterfall memiliki beberapa tahapan yaitu: requirement (analisis kebutuhan), design system (desain sistem), Coding (pengkodean) \& Testing (pengujian), penerapan program, pemeliharaan. Tahapantahapan dari metode waterfall sebagai berikut:

1) Requirement Analisis

Tahap pengembang sistem adalah komunikasi yang untuk memahami perangkat lunak yang diharapkan oleh pengguna dan batasan perangkat lunak tersebut. Informasi ini biasanya dapat diperoleh melalui wawancara, diskusi atau survei langsung. Informasi di analisis untuk mendapatkan data yang dibutuhkan oleh pengguna.

2) System Design

Desain Sistem merupakan spesifikasi yang membantu dalam menentukan perangkat keras dan design sistem juga membantu dalam mendefinisikan arsitektur sistem secara keseluruhan.

3) Implementation

Implementasi merupakan tahapan-tahapan dalam merancang sebuah sistem. Setiap tahapan pada unit perangkat lunak dikembangkan dan diuji fungsionalitasnya yang disebut unit testing.

4) Integration \& Testing

Tahap ini merupakan tahap perancangan perangkat lunak telah selesai sebagai program dan unit program lalu pengujian unit telah diverifikasi pada setiap unitnya yang telah memenuhi spesifikasinya.

5) Operation \& Maintenance

Tahap akhir dalam model waterfall. Perangkat lunak yang sudah jadi, di jalankan serta dilakukan pemeliharaan termasuk dalam memperbaiki kesalahan yang tidak ditemukan pada langkah sebelumnya.

\subsection{Pengertian Aplikasi}

Aplikasi yang dimaksud pada penelitian ini merupakan sebuah software yang dirancang khusus pada penjualan tunai saja. Aplikasi adalah suatu program komputer yang dibuat dengan bahasa pemrograman yang 
menggunakan ketentuan dan aturan tertentu untuk mengerjakan dan melaksanakan tugas khusus dari pengguna [3].

\subsection{Pengertian Website}

Website adalah halaman informasi yang disediakan melalui jalur internal sehingga bisa diakses di seluruh dunia secara global, selama masih terkoneksi dengan jaringan internet [2]. Selain itu, website juga dapat diartikan sebagai kumpulan halaman yang bersifat statis maupun dinamis membentuk satu rangkaian bangunan saling terkait, dimana masing-masing dihubungkan dengan jaringan-jaringan halaman atau dikenal dengan hyperlink yang dapat menampilkan informasi data teks, data gambar, data animasi, suara, video dan gabungan dari semuanya [1].

\section{HASIL}

\subsection{Use Case Diagram}

Use case diagram menunjukkan interaksi antara use case, actor, dan pekerja. Diagram ini menggambaran model lengkap tentang apa yang perusahaan CV. Damar Abadi Pontianak lakukan, siapa yang berperan baik di dalam maupun di luar. Adapun Use Case Diagram tersebut yaitu sebagai berikut:

1. Use Case Diagram Admin

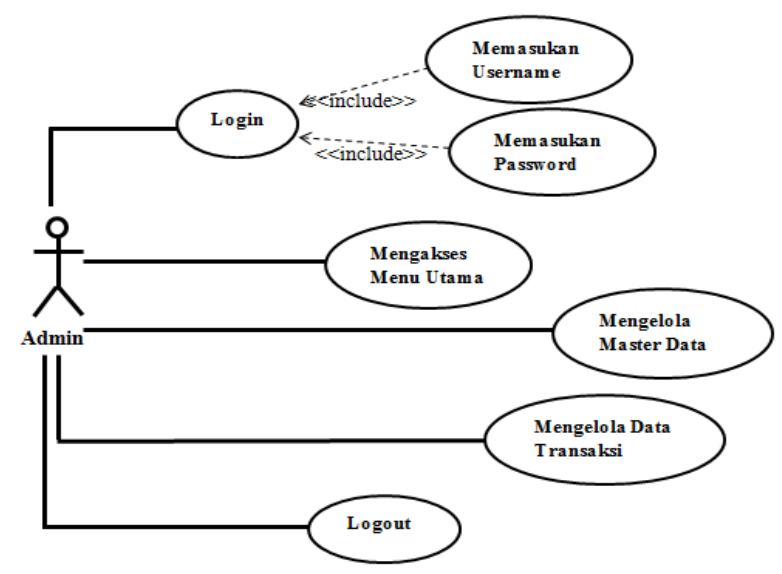

Sumber: Hasil Penelitian (2020)

\section{Gambar 1. Use Case Akses Admin}

2. Use Case Diagram Akses Pimpinan

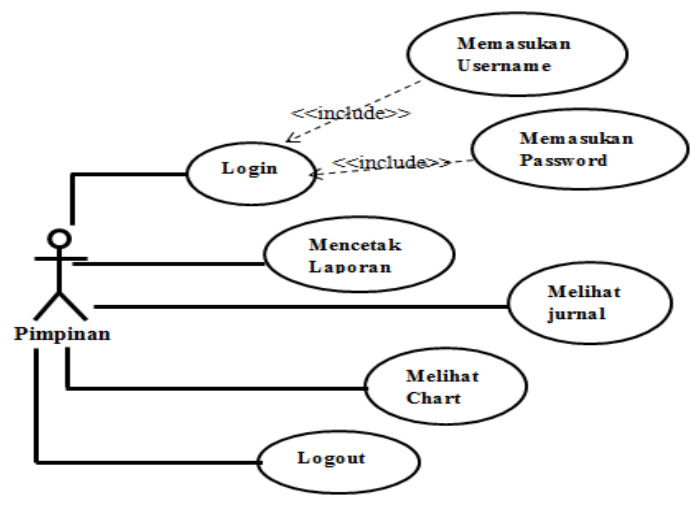

Sumber: Hasil Penelitian (2020)

\section{Gambar 2. Use Case Akses Pimpinan}

\subsection{Activity Diagram}

Activity Diagram menggambarkan tentang alir aktivitas dalam program yang sedang dirancang, bagaimana masing-masing proses alir berawal, decision yang mungkin terjadi dan bagaimana program 
berakhir. Activity Diagram juga dapat menggambarkan proses paralel yang mungkin terjadi pada beberapa eksekusi.

1. Activity Diagram Admin

a. Activity Diagram Halaman Utama

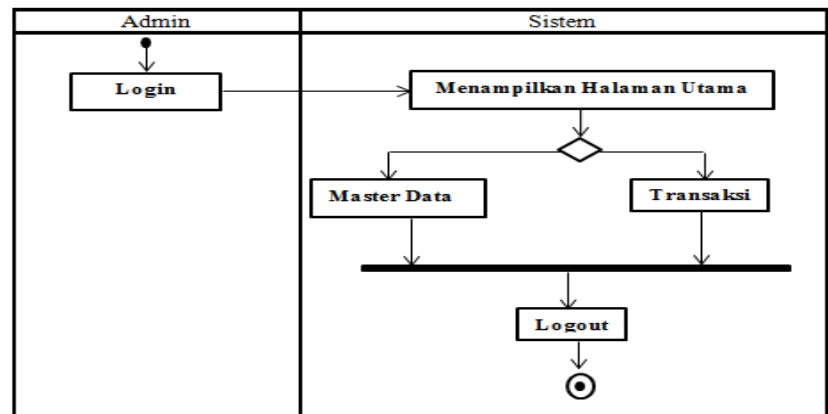

Sumber: Hasil Penelitian (2020)

Gambar 3. Activity Diagram Mengolah Halaman Utama Admin

Pada halaman Gambar 3. di atas menunjukkan diagram aktivitas untuk mengolah halaman utama (Home). Berisi menu master data dan menu transaksi.

\section{b. Activity Diagram Mengelola Master Data}

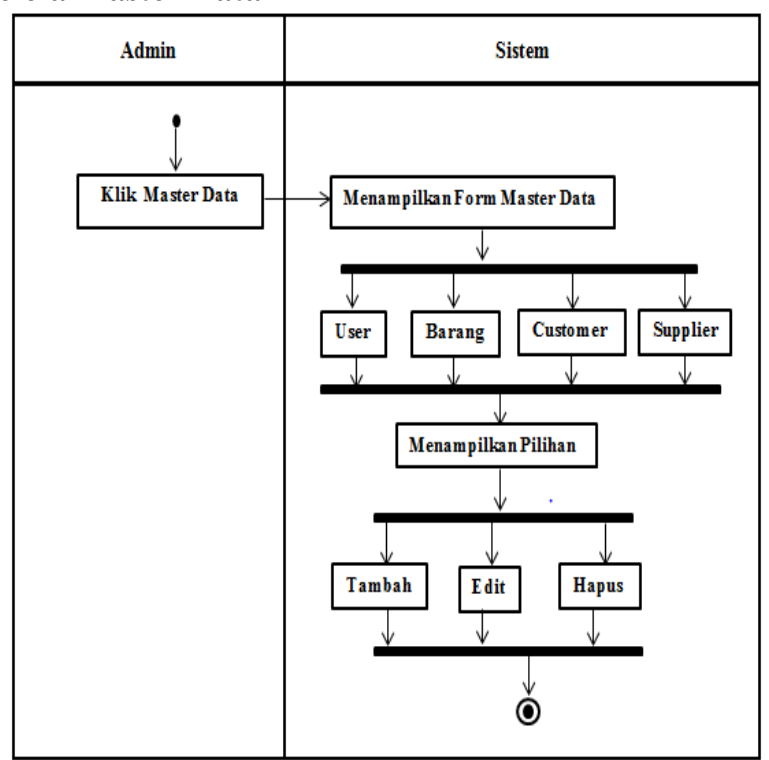

Sumber: Hasil Penelitian (2020)

Gambar 4. Activity Diagram Mengolah Master Data

Pada Gambar 4. di atas menunjukkan aktivitas yang dapat dilakukan di halaman master data beserta menumenu yang terdapat disana. Berisi menu form User, Barang, Customer, dan Supplier.

\section{c. Activity Diagram Mengolah Data Transaksi}

Pada activity diagram di bawah ini digunakan untuk mengolah data transaksi beserta menu-menu yang ada di dalamnya. Berisi menu transaksi pembelian dan transaksi penjualan. Berikut gambarnya. 


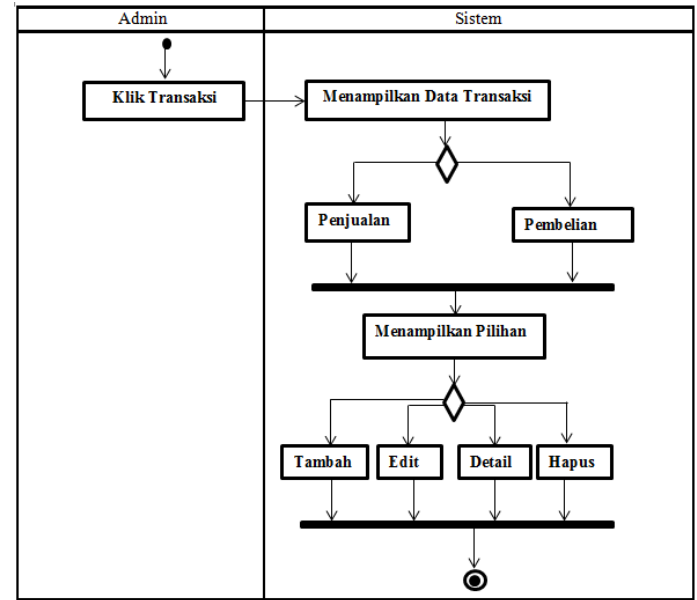

Sumber: Hasil Penelitian (2020)

Gambar 5. Activity Diagram Mengolah Data Transaksi

2. Activity Diagram Akses Pimpinan

a. Activity Diagram Halaman Utama

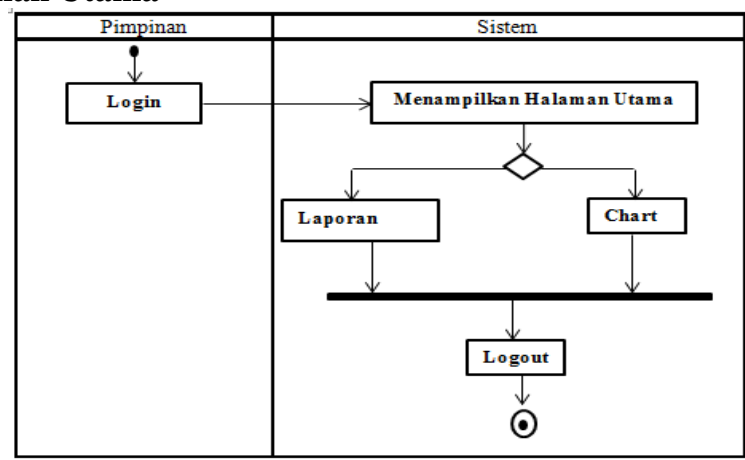

Sumber: Hasil Penelitian (2020)

Gambar 6. Activity Diagram Halaman Utama Pimpinan

b. Activity Diagram Mencetak Laporan

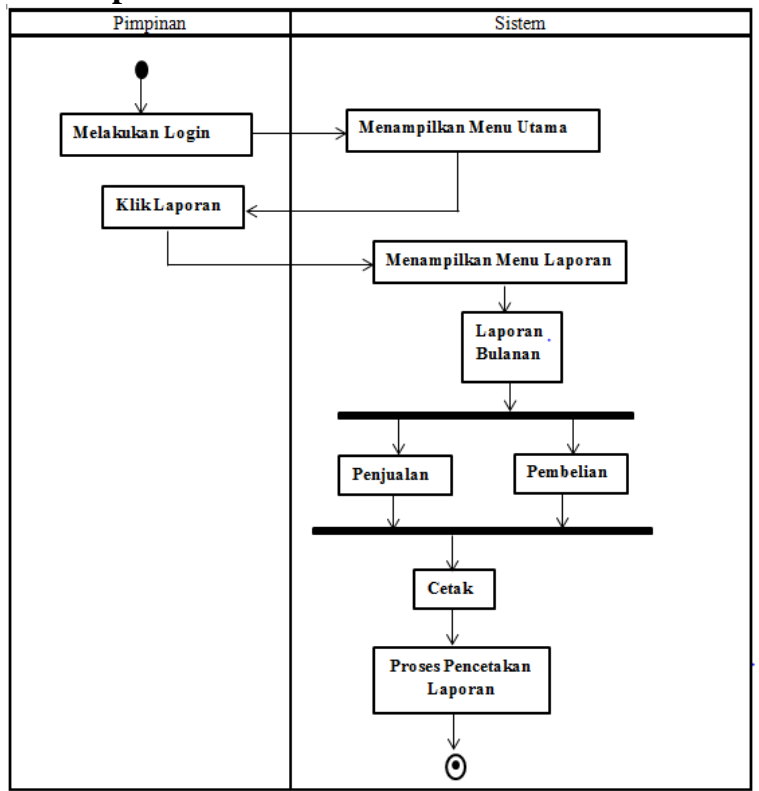

Sumber: Hasil Penelitian (2020)

Gambar 7. Activity Diagram Mencetak Laporan 


\section{c. Activity Diagram Tampilan Chart}

Berikut adalah tampilan untuk melihat activity diagram Chart, dimana ada grafik yang didapatkan dari transaksi penjualan dan pembelian.

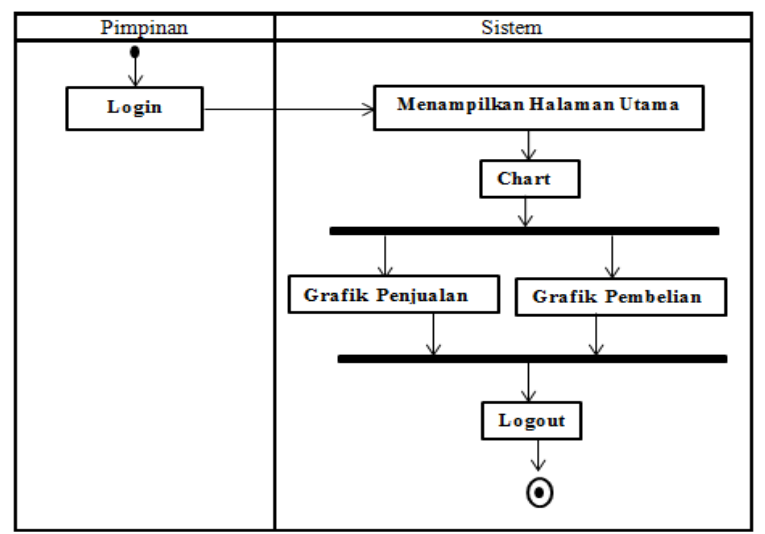

Sumber: Hasil Penelitian (2020)

Gambar 8. Activity Diagram Tampilan Chart

\subsection{User Interface}

User Interface merupakan tampilan visual yang menjembatani sistem dengan pengguna. Tampilan user interface berupa bentuk, warna, dan tulisan yang di desain. Adapun tampilan user interface aplikasi penjualan tunai berbasis web pada CV. Damar Abadi Pontianak yaitu sebagai berikut:

1. Tampilan Login

Untuk dapat mengakses aplikasi ini aktor harus melakukan login terlebih dahulu dengan memasukkan username dan password dengan benar kemudian klik login.

Sumber: Hasil Penelitian (2020)

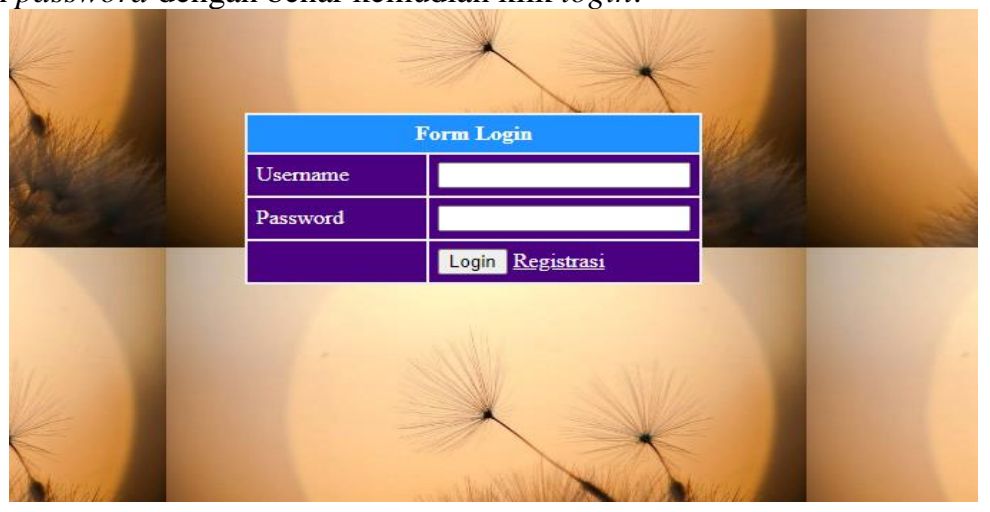

\section{Gambar 9. Tampilan Login}

2. Tampilan Menu Utama Hak Akses Admin

Setelah admin memasukan username dan password dengan benar dan berhasil login, admin dapat mengakses menu utama yaitu admin dapat mengakses master data, transaksi dan melakukan logout.

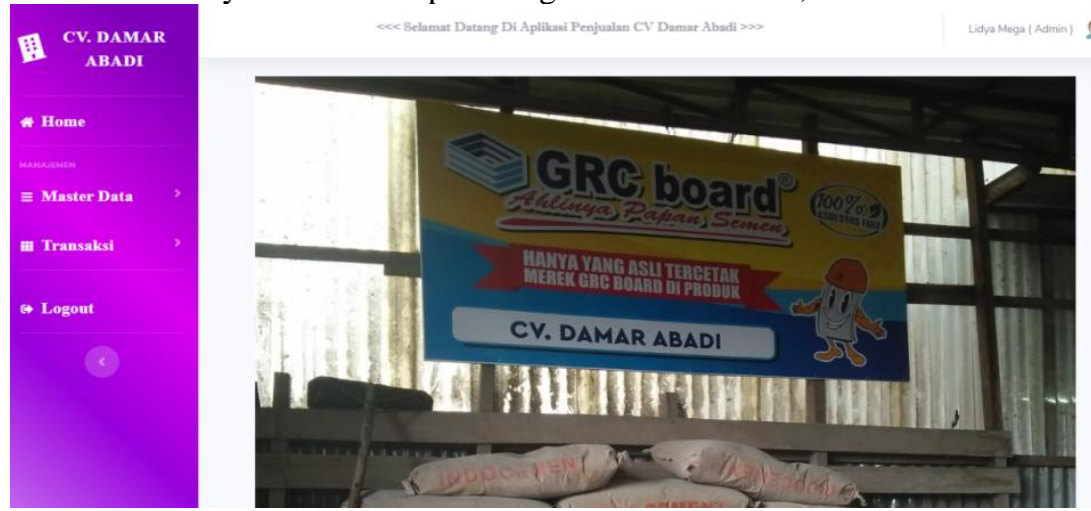

Sumber: Hasil Penelitian (2020)

Gambar 10. Tampilan Menu Utama Akses Admin 
Setelah berhasil masuk ke menu utama maka admin dapat mengelola master data serta dapat mengelola submenu-submenu di dalamnya seperti: user, barang, customer dan supplier.

3. Hak Akses Pimpinan

Setelah pimpinsn memasukan username dan password dengan benar dan berhasil login, pimpinan dapat mengakses menu utama yaitu dapat mengakses laporan, chart dan melakukan logout.
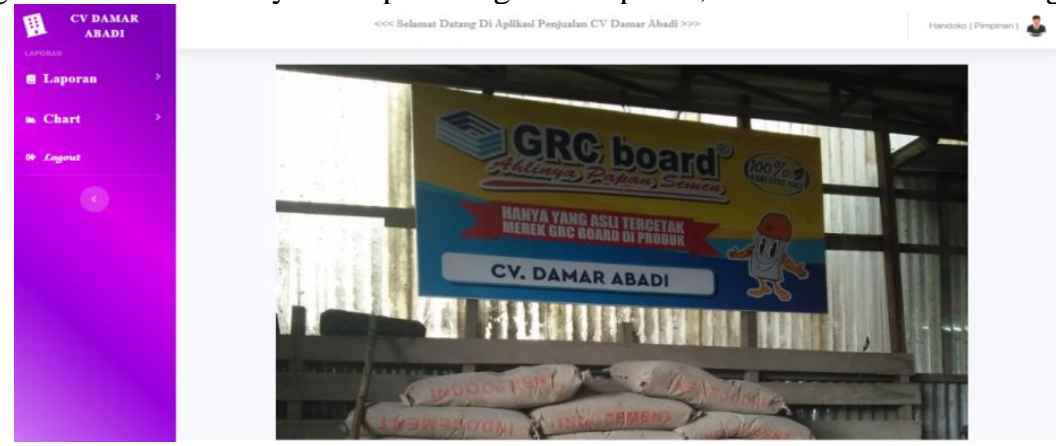

Sumber: Hasil Penelitian (2020)

Gambar 11. Tampilan Menu Utama Hak Akses Pimpinan

\section{KESIMPULAN}

Berdasarkan identifikasi masalah dan hasil analisa dari aplikasi penjualan tunai berbasis Web pada CV.

Damar Abadi Pontianak maka dapat disimpulkan sebagai berikut:

1. Dari hasil analisis pada sistem yang sedang berjalan dapat dilihat adanya kendala atau masalah yang dihadapi CV. Damar Abadi Pontianak terutama dalam proses transaksi penjualan tunai. Dalam penyimpanan data atau dokumen transaksi penjualan pada CV. Damar Abadi Pontianak masih dalam bentuk arsip kertas, sehingga memerlukan tempat penyimpanan yang besar dan lambatnya proses pencarian dikarenakan harus mencari diantara tumpukan-tumpukan arsip serta ketidak efisienan data dikarenakan banyak arsip yang hilang.

2. Dengan adanya aplikasi penjualan tunai berbasis Web ini maka pekerjaan di CV. Damar Abadi Pontianak khususnya dalam penjualan tunai akan lebih mudah dan sistem pengarsipan ini juga bisa di akses kembali jika sewaktu-waktu diperlukan sehingga bisa menampung data arsip beberapa tahun meskipun data arsip fisik sudah rusak.

3. Dengan adanya aplikasi penjualan tunai berbasis Web ini, maka pembuatan laporan akan lebih cepat serta mengurangi resiko kehilangan data.

\section{REFERENSI}

[1] Destiningrum, M., \& Adrian, Q. J. (2017). Sistem Informasi Penjadwalan Dokter Berbassis Web Dengan Menggunakan Framework Codeigniter (Studi Kasus: Rumah Sakit Yukum Medical Centre). Jurnal Teknoinfo. https://doi.org/10.33365/jti.v11i2.24

[2] Handayani, V. R., Wijianto, R., \& Anggoro, A. (2018). Sistem Informasi Pendaftaran Seleksi Kerja Berbasis Web pada BKK (Bursa Kerja Khusus) Tunas Insan Karya SMK Negeri 2 Banyumas. Jurnal Evolusi, Vol. 6(No. 1), 76-84.

[3] Maarif, V., Nur, H. M., \& Rahayu, W. (2018). Aplikasi Pembelajaran Ilmu Tajwid Berbasis Android. Jurnal Evolusi, vol 6(no 1), 91-100.

[4] Rosa AS dan M.Shalahuddin. 2015. Rekayasa Perangkat Lunak Terstruktur Dan Berorientasi Objek.Bandung: Informatika. Cetakan Ketiga. 